\title{
Seasonal variation in denitrification and dissolved nitrogen fluxes in intertidal sediments of the Tagus estuary, Portugal
}

\author{
Maria Teresa Cabrita*, Vanda Brotas \\ Instituto de Oceanografia, Faculdade de Ciências da Universidade de Lisboa, Campo Grande, 1749-016 Lisboa, Portugal
}

\begin{abstract}
Dissolved nitrogen fluxes and denitrification were studied during 1 yr in intertidal sediments of the Tagus estuary (Portugal). This study focused on the factors regulating both nitrogen fluxes across the sediment-water interface and denitrification, and on the effect of microphytobenthos activity in controlling nitrogen cycling in these areas. Sampling was performed monthly at 2 stations located in inner and outer intertidal areas. Fluxes of $\mathrm{O}_{2}, \mathrm{NO}_{3}{ }^{-}, \mathrm{NO}_{2}{ }^{-}, \mathrm{NH}_{4}{ }^{+}$and $\mathrm{N}_{2} \mathrm{O}$, and denitrification (determined by the nitrogen-isotope pairing technique) were measured simultaneously in closed chambers incubated in the laboratory under simulated in situ temperature and light conditions, as well as in the dark. At the sediment-water interface, higher DIN fluxes and lower denitrification rates were registered at higher temperatures and lower $\mathrm{NO}_{3}{ }^{-}$concentration in the water column. Oxygen uptake by the sediment was generally higher than release, particularly in summer. Primary productivity displayed a seasonal cycle, positively influenced by temperature. Denitrification rates were closely related to $\mathrm{NO}_{3}{ }^{-}$river-input. Temperature, $\mathrm{NO}_{3}{ }^{-}$concentration in the water column, microphytobenthos, infauna and tidal height were the key parameters involved in controlling nitrogen cycling at the sediment-water interface in the Tagus estuary. A comparison of annual nitrogen fluxes and denitrification rates between sites was made, taking into account tidal immersion periods. Hence, N-removal by denitrification accounted for $156 \mathrm{mmol} \mathrm{m} \mathrm{yr}^{-1}$ in the inner station and $482 \mathrm{mmol} \mathrm{m}^{-2} \mathrm{yr}^{-1}$ in the outer station. These rates represent respectively ca 3 and $9 \%$ of total DIN available in the estuarine water column at those 2 stations, respectively. $\mathrm{N}_{2} \mathrm{O}$ production was comparatively very low $\left(0.3\right.$ to $\left.0.6 \mathrm{mmol} \mathrm{m}^{-2} \mathrm{yr}^{-1}\right)$. The estimated nitrogen assimilation rates by microphytobenthos were $707 \mathrm{mmol} \mathrm{m}^{-2} \mathrm{yr}^{-1}$ in the inner station and $333 \mathrm{mmol} \mathrm{m}^{-2} \mathrm{yr}^{-1}$ in the outer station, indicating that a considerable amount of nitrogen was retained within benthic microalgae. The assimilation/denitrification ratio, with a mean value of 2 , shows the relative importance of the denitrification role as a N-sink. Apart from denitrification, it is suggested that other processes must be involved in the removal of nitrogen from the estuary.
\end{abstract}

KEY WORDS: DIN fluxes · Denitrification · Microphytobenthos $\cdot$ Intertidal sediments $\cdot$ Tagus estuary

Resale or republication not permitted without written consent of the publisher

\section{INTRODUCTION}

The understanding of nitrogen processes in estuarine and coastal systems has become an increasingly important issue, stressed by the growing awareness in evaluating the value of natural ecosystems (Constanza et al. 1997). Gradually more nitrogen is being

*E-mail: tcabrita@fc.ul.pt discharged into the estuaries, both by riverine and direct anthropogenic inputs, changing the trophic status of the systems themselves and influencing the amount of nitrogen output to the atmosphere and adjacent coastal waters. Although estuaries have been reported to be important nitrogen sinks (Seitzinger 1988), the magnitude of the attenuation of the nitrogen load and the relative importance of processes involved in nitrogen removal are still poorly understood. 
Estuarine sediments play an important role in nutrient cycling. In general, sediments are considered as large sinks for organic matter and oxygen; as a result of remineralization, intense exchanges between the sediment and water column occur (Nixon 1981). Sediments may be sources of some nutrients and sinks for others, depending on the biogeochemical transformations occurring at the sediment-water interface. With regard to nitrogen, sediments generally represent an important source of $\mathrm{NH}_{4}^{+}$(Boynton \& Kemp 1985, Rizzo 1990) and a sink for $\mathrm{NO}_{3}{ }^{-}$(Seitzinger et al. 1984, Nedwell \& Trimmer 1996). Denitrification is known to remove nitrogen by bacterial reduction of $\mathrm{NO}_{3}^{-}$to nitrogen gas via $\mathrm{NO}_{2}^{-}$in anoxic sediment environments, and may be based on both $\mathrm{NO}_{3}{ }^{-}$diffusing from the water column into the sediments and on $\mathrm{NO}_{3}{ }^{-}$produced by nitrification (Seitzinger 1988). The discrimination of these 2 components is extremely useful in better evaluating denitrification (Nielsen 1992, Rysgaard et al. 1993, Risgaard-Petersen et al. 1994). The importance of denitrification as a N-removal process is still a matter of debate, since a wide range of removal percentages attributed to this process are found in estuaries. In some estuaries, denitrification may remove up to $40-50 \%$ of the nitrogen entering as DIN (Seitzinger et al. 1984, 1987); this represents a considerable reduction in the amount of nitrogen exported to the ocean and an important removal pathway for excess anthropogenic nitrogen inputs. In some estuaries, denitrification seems to be of minor importance in terms of overall mineralization (Christensen et al. 1990). Several environmental factors may regulate these processes, such as organic matter produced in the sediments (Nixon 1981, Jensen et al. 1990), the chemical status of the surface sediments and the water column (Koop et al. 1990), and both benthic fauna (Pelegrí et al. 1994) and flora (Rizzo 1990, Sundbäck et al. 1991, Rysgaard et al. 1995) activity. In a natural system, all these factors interact dynamically, which makes it very difficult to identify which factor(s) controls which process(es).

This study reports on dissolved inorganic nitrogen (DIN) fluxes and $\mathrm{N}_{2} \mathrm{O}$ and $\mathrm{N}_{2}$ removal by denitrification at the sediment-water interface of the intertidal sediments of the Tagus estuary. No measurements of denitrification for this estuary exist, and little is known regarding DIN fluxes across the sediment-water interface during periods of immersion. These exchange processes were investigated on a seasonal basis to identify the environmental factors controlling them. Particular emphasis was placed on the effect of microphytobenthos activity on nutrient fluxes (evaluated by comparing flux rates under light and dark conditions), as benthic microalgae are the main primary producers in the intertidal sediments of the Tagus estuary.
Finally, estimates of nitrogen fluxes and removal were calculated on an annual basis, taking into account sediment submersion periods.

\section{MATERIALS AND METHODS}

Study area. The Tagus estuary, one of the largest estuaries $\left(320 \mathrm{~km}^{2}\right)$ in Europe, is located on the densely populated west coast of Portugal $\left(38^{\circ} 44^{\prime} \mathrm{N}, 9^{\circ} 08^{\prime} \mathrm{W}\right)$ (Fig. 1). The estuary has a broad, shallow inner bay with extensive intertidal areas. This mesotidal estuary, has semi-diurnal tides with amplitudes varying from $\sim 1 \mathrm{~m}$ at neap tide to $\sim 4 \mathrm{~m}$ at spring tide. The river flow fluctuates seasonality with an average monthly discharge varying from 145 in summer to $813 \mathrm{~m}^{3} \mathrm{~s}^{-1}$ in winter (results from a 34 yr data base), which corresponds to a residence time of 26 and $8 d$, respectively. The total annual $\mathrm{N}^{-\mathrm{NO}_{3}}{ }^{-}$loading into the estuary was $26000 \mathrm{t}$ in 1997. Sampling was carried out at 2 stations, Pancas (P) and Rosário (R), which are situated at the inner and outer geographic sections of the estuary (Fig. 1); Pancas is located on the upper eulittoral zone and Rosário at the lower eulittoral zone. At each station, 2 sites perpendicular to the shore line were examined to account for local heterogeneity. At Pancas, P1 and P2 (tidal height of 2.7 and $2.9 \mathrm{~m}$, respectively) were about $400 \mathrm{~m}$ apart, at Rosário, R1 (1.4 m) and R2 $(2.0 \mathrm{~m})$ were separated by $250 \mathrm{~m}$ (tidal heights are given in relation to hidrographic zero which is in Lisbon, $2.2 \mathrm{~m}$ below mean sea level).

Sampling program. Sampling of sediment parameters was conducted from January 1997 to April 1998. Flux measurements started in May 1997, and ended in April 1998. One site at each station was sampled monthly, the other every 3 mo, always during the spring low tides. Sediment samples were collected with corers of 4 different dimensions (diameter $\times$ length), each for a distinct purpose: flux measurements $(8.0 \times 35.0 \mathrm{~cm}) ;$ microalgal cell collection $(8.0 \times$ $13.0 \mathrm{~cm})$; pigment analysis and other sediment characteristics $(3.6 \times 10.0 \mathrm{~cm})$; oxygen profiles $(1.9 \times 10.0 \mathrm{~cm})$. Surface sediment ( 0 to $5 \mathrm{~mm}$ ) was collected with a spatula for porewater-nutrient analyses. Samples were brought to the laboratory for further processing and incubation procedures. Photosynthetically available radiation (PAR), measured with a LI-COR-192SA underwater quantum sensor, and top first cm sediment temperature were determined at each site (P1, P2, R1 and R2) during sampling. On the same day, estuarine water for the incubation experiments was collected during high tide near the sampling sites, and filtrated through a $500 \mu \mathrm{m}$ mesh. Porewater and water column salinity was measured with an ATAGO S/Mill-E refractometer (0.5 accuracy). 


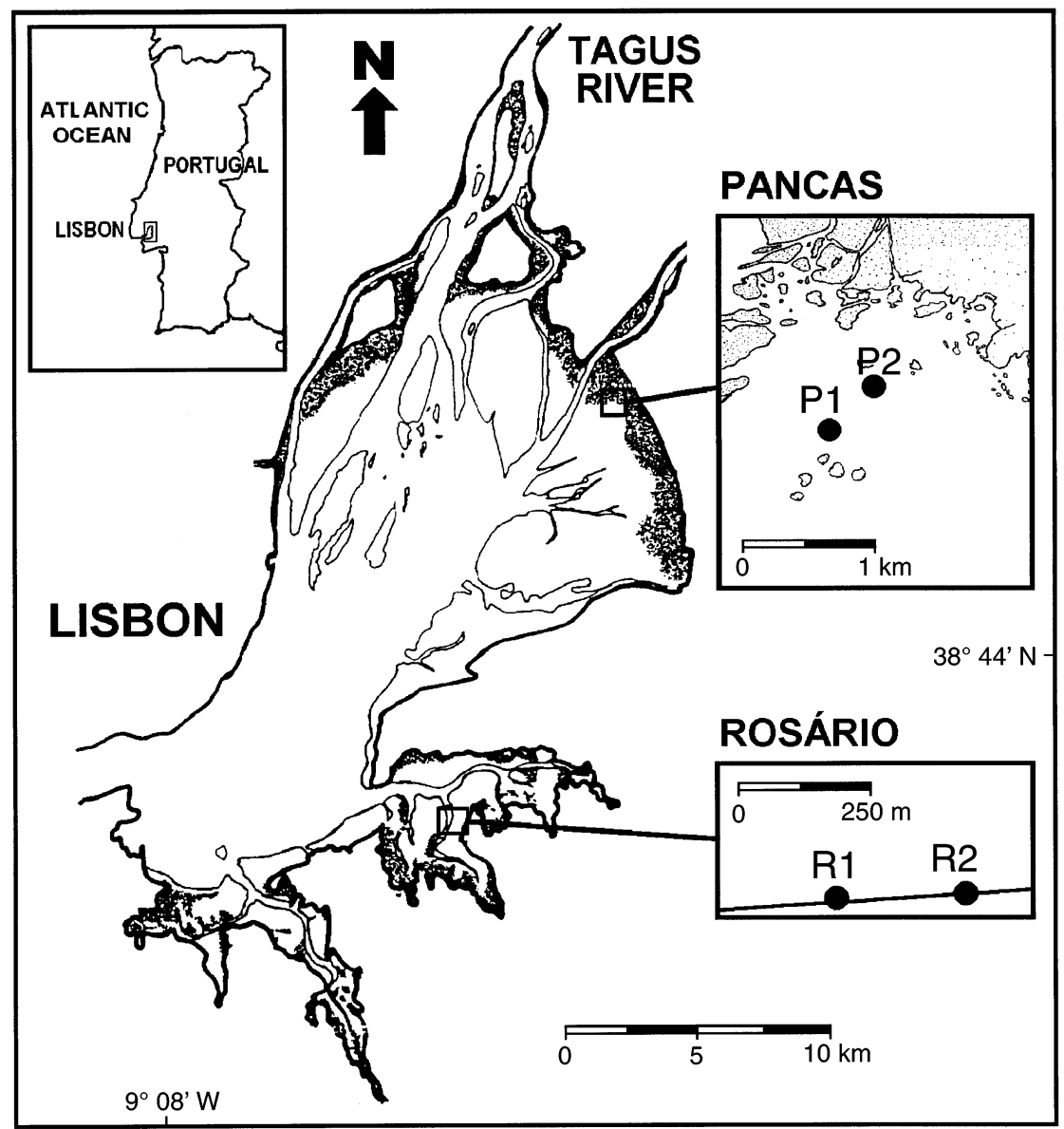

Fig. 1. Map of the Tagus estuary showing the 4 sampling sites (P1, P2, R1 and R2) located in the upper and lower intertidal areas of the estuary. Hatched areas $=$ saltmarsh. Thin line $=$ lower limit of intertidal zone

Sediment characteristics. Sediment porosity was determined from the dry and wet weights of known sediment volumes. Sediment granulometry was determined by sequential sediment-sieving to evaluate the relative abundance ( $\%$ dry wt) of $2,1,0.5,0.35$, $0.5,0.125,0.063$ and $<0.063 \mathrm{~mm}$ size-fractions. Water content was determined as the percentage of water in relation to the total fresh sediment weight. Sediment organic matter was measured as percentage of weight loss by ignition $\left(500^{\circ} \mathrm{C}, 2 \mathrm{~h}\right)$ from the $100^{\circ} \mathrm{C}$ dried sediment. Carbon and nitrogen contents were determined in duplicated sub-samples taken from surface sediment, by a CHN Analyzer (EA 1108, Fisons Instruments SPA, Italy). Sediment porewater was obtained by centrifugation and samples were taken for $\mathrm{NO}_{3}^{-}, \mathrm{NO}_{2}{ }^{-}, \mathrm{NH}_{4}{ }^{+}$and $\mathrm{PO}_{4}{ }^{3-}$ analyses. Oxygen profiles were measured on undisturbed sediment corers exposed to air with a Clark Type oxygen microelectrode (5 to $20 \mu \mathrm{m}$ tip 737-GC) from Diamond General, Michigan, USA, on the day following sampling.
Benthic communities. Benthic microalgae biomass was measured as chlorophyll a ( $\mathrm{chl}$ a) concentration in the top $0.5 \mathrm{~cm}$ of sediment, determined by the method of Lorenzen (1967). Direct observations of the sediments on the microscope showed that the microphytobenthos community was dominated by motile algal cells. Therefore, samples for cell counts and species composition were collected by the lens-tissue technique (Eaton \& Moss 1966) in order to recover the epipelic fraction. On the day following sampling, pieces of $2 \times 2 \mathrm{~cm}$ lens tissue were placed on the surface of the sediment corers, which were exposed to natural light for $2 \mathrm{~h}$. Immediately after collection, the lens tissue was placed in a flask with filtered local water with added glutaraldehyde (final concentration $2.5 \%$ ). Before microscopic examination, each lens tissue was shredded and the flask was placed in an ultrasonic bath for $15 \mathrm{~min} ; 0 \mu \mathrm{l}$ of the solution were then mounted on a microscopic slide. Specific composition was quantified with 400x magnification, under an Olympus BX50 microscope. A given number of optical 
fields was examined to obtain a count of at least 100 cells, to enable the determination of relative abundance of dominating taxa.

Benthic fauna biomass and species identification were also determined within each core used for flux measurements. Infauna was recovered by sedimentsieving with a $500 \mu \mathrm{m}$ mesh, and biomass was determined as wet weight. Weighted biomass was then preserved in a solution of formalin with Bengal Rose until species counting, and identification were performed under a compound microscope.

DIN flux measurements. Flux measurements were performed under controlled laboratory conditions (Dalsgaard et al. 2000). Immediately after arrival at the laboratory, flux corers were carefully filled with estuarine water, to avoid sediment resuspension and to preserve sediment structure, and left open immersed in estuarine water inside an incubator, at in situ temperature (measured during sampling) for $24 \mathrm{~h}$. Incubations started the next day, at the same time low tide was actually occurring in the field, to correspond with the semi-diurnal microalgal migration cycle. Corers were then closed with rubber stoppers and incubation was started under simulated in situ temperature and irradiance conditions, as well as in the dark, and also under controlled stirring conditions. Stirring in the corers was obtained by a central rotating $4 \mathrm{~cm}$ Teflon coated magnet bar, suspended $6 \mathrm{~cm}$ above the sediment surface. An external rotating magnet, located in the center of the incubation device, drove the stirring bars inside the corers. The stirring intensity was regulated to insure that the sediment surface was not disturbed but the water column could be homogenized. The incubation irradiance level for each sampling date was the average irradiance of the corresponding month. This value was estimated from hourly irradiances obtained from a 3 yr irradiance data set. One set of 3 corers was incubated in the light and 1 set of 3 corers in darkness, for each sampling site. Incubation time, which varied from 1 to $5 \mathrm{~h}$, was adjusted to ensure that $\mathrm{O}_{2}$ uptake in the corers never diminished the initial $\mathrm{O}_{2}$ concentration by more than $20 \%$. Water samples were collected just before closing the corers and after the incubation. Water samples were immediately analyzed for $\mathrm{O}_{2}$ concentration. Samples for $\mathrm{NH}_{4}{ }^{+}, \mathrm{NO}_{2}{ }^{-}, \mathrm{NO}_{3}{ }^{-}$and $\mathrm{N}_{2} \mathrm{O}$ determination were previously filtered. $\mathrm{N}_{2} \mathrm{O}$ samples were preserved with $100 \mu \mathrm{l}$ of $38 \%$ formaldehyde solution and stored in gas-tight vials (Exetainers, Labco, High Wycombe, UK) until analysis. Samples for DIN determination were immediately frozen for later analysis.

Denitrification measurements. Following measurements of oxygen and DIN fluxes, denitrification was determined on the same sediment corers in accordance with the nitrogen-isotope pairing technique (Nielsen
1992). Denitrification was measured on 1 set of 3 corers in the light and 1 set of 3 in darkness, at the same light and temperature conditions and for the same time period as used for the nutrient flux measurements. Cores were filled with estuarine water collected at the sampling site. Nitrate labelled with ${ }^{15} \mathrm{~N}$ was then added to each core, corresponding to $30 \%$ or more of the in situ concentration of $\mathrm{NO}_{3}{ }^{-}$in the water column. The ${ }^{15} \mathrm{NO}_{3}{ }^{-}$solution was made using $\mathrm{Na}^{15} \mathrm{NO}_{3}$ (98 atom $\%{ }^{15} \mathrm{~N}$, ISOTEC Isotopes). Just before incubation, samples of the water column were collected for analysis of the ${ }^{15} \mathrm{~N}$-labelling of $\mathrm{N}_{2}$ and $\mathrm{NO}_{3}{ }^{-}$concentrations (time zero values). Incubation time was the same as for the DIN fluxes incubations, to insure that $\mathrm{O}_{2}$ uptake in the corers never decreased the initial $\mathrm{O}_{2}$ concentration by more than $20 \%$. After incubation, water samples were taken for $\mathrm{NO}_{3}{ }^{-}$analyses immediately upon removal of the stopper. One $\mathrm{ml}$ of $\mathrm{ZnCl}_{2}$ solution $(50 \% \mathrm{w} / \mathrm{w})$ was then immediately added to the corers to stop all bacterial activity, and the water column and sediment porewater were carefully mixed using a Plexiglas rod. The sediment slurry was gently sampled with a syringe. Water and sediment slurry samples, both for ${ }^{15} \mathrm{~N}$ isotope analysis, were preserved in gas-tight exetainers with $250 \mu \mathrm{l}$ of $\mathrm{ZnCl}_{2}$ solution. Finally, the sediment corers were sieved through a $500 \mu \mathrm{m}$ sieve to recover benthic fauna.

Chemical analyses. Oxygen concentrations were determined by Winkler titration (Strickland \& Parsons 1972). Samples for nutrient analyses were filtered through Whatman GF/F glass-fibre filters. $\mathrm{NH}_{4}{ }^{+}$was analysed manually according to Koroleff (1969/1970). Samples for $\mathrm{NO}_{3}{ }^{-}, \mathrm{NO}_{2}{ }^{-}$and $\mathrm{PO}_{4}{ }^{3-}$ were frozen and analysed later, on a flow injection analyzer (Tecator, Sweden). Concentrations of $\mathrm{NO}_{3}{ }^{-}$and $\mathrm{NO}_{2}{ }^{-}$were measured according to Grasshoff (1964) and Bendschneider \& Robison (1952), respectively. $\mathrm{PO}_{4}{ }^{3-}$ was determined by the method described by Murphy \& Riley (1962). $\mathrm{N}_{2} \mathrm{O}$ concentration was determined by electron-capture gas-chromatography (Rasmussen et al. 1976). The formation of ${ }^{15} \mathrm{~N}$-labelled dinitrogen pairs $\left({ }^{14} \mathrm{~N}^{15} \mathrm{~N}\right.$ and $\left.{ }^{15} \mathrm{~N}^{15} \mathrm{~N}\right)$ by denitrification was measured on an isotope ratio-mass spectrometer, as described by Nielsen (1992).

Calculations. Fluxes of $\mathrm{O}_{2}, \mathrm{NH}_{4}{ }^{+}, \mathrm{NO}_{2}{ }^{-}, \mathrm{NO}_{3}{ }^{-}$and $\mathrm{N}_{2} \mathrm{O}$ were calculated for each core from the change in concentration during incubation, and expressed as rate per square meter.

Gross primary production (GP) was calculated based on the measurement of $\mathrm{O}_{2}$ production in the light plus the dark $\mathrm{O}_{2}$ uptake values. Nitrogen assimilation by microphytobenthos was estimated from primary production rates, using photosynthetic quotient of 1.2 and a carbon:nitrogen ratio of 9 (mol:mol) (Sundbäck et al. 2000). As measured values of net production (NP) were 
often negative because of strong sediment uptake, NP rates were estimated from GP values, using an NP:GP ratio of 0.80, as determined by Brotas \& Catarino (1995) for similar sites in Tagus estuary.

Denitrification rates $\left(D_{14}\right.$ and $\left.D_{15}\right)$ were calculated using production rates of single-labelled $\left({ }^{14} \mathrm{~N}^{15} \mathrm{~N}\right)$ and double-labelled $\left({ }^{15} \mathrm{~N}^{15} \mathrm{~N}\right)$ dinitrogen pairs according to Nielsen (1992). Denitrification based on $\mathrm{NO}_{3}{ }^{-}$from the water column $\left(D_{\mathrm{w}}\right)$ was calculated from $D_{15}$ and the ${ }^{14} \mathrm{~N}:{ }^{15} \mathrm{~N}$ ratio of water column $\mathrm{NO}_{3}{ }^{-}$. Coupled nitrification-denitrification $\left(D_{\mathrm{n}}\right)$ was determined by the difference between $D_{14}$ and $D_{\mathrm{w}}$.

Incubation conditions from this study only simulated natural conditions when sediments were immersed; therefore, to estimate annual values, only dark fluxes were used. Annual fluxes were obtained by multiplying hourly dark flux values and immersion time percentage which was $34 \%$ for P1 and $78 \%$ for R1.

\section{RESULTS}

\section{Sediment characteristics}

Several sediment parameters for the 4 sampling sites are presented in Table 1, which presents the range and average of values obtained for each parameter during the sampling period. Sediments at the inner station (Pancas) were finer, and therefore of higher porosity, water content and organic matter. Granulometry and surface porosity neatly distinguished R2 from the other sites. Porewater dissolved nitrogenous nutrients were considerably lower at P1 and P2 than at R1 and R2. $\mathrm{PO}_{4}{ }^{3-}$ concentrations were similar at the 4 sites as well as $\mathrm{C}: \mathrm{N}$ ratio and $\mathrm{O}_{2}$ penetration.

\section{Benthic communities}

Temporal variation of microphytobenthos biomass, measured as chl a concentration, at the 4 sites is shown in Fig. 2. Differences between sites from the same intertidal station were more evident at outer area of the estuary (R). Exceptionally high biomass values in parallel with unusual high temperature values were observed in winter 1997. R1 and R2 presented a clear seasonal pattern, with highest biomass recorded during spring and summer. Diatoms dominated benthic algal communities at the 4 sites (90 to $100 \%$ of total motile cells). Navicula phyllepta and Navicula gregaria were found to be the most abundant and more representative species, since these 2 species together contributed to a monthly average of $80 \%$ of the total cell community, during the sampling period at the 4 sites. Other species, such as Cylindrotheca closterium, Gyrosigma fasciola, Pleurosigma angulatum, Surirella ovata and an Amphiprora species, also contributed to the specific diversity of these microphytobenthic communities. Ocasionally, filamentous and colonial cianobacteria, as well as Euglena sp. were present.

Table 1. Ranges and monthly averages (values in bold) of some physical and chemical parameters of sediment from sampling sites located in the upper (P1, P2) and lower (R1, R2) intertidal areas of the Tagus estuary

\begin{tabular}{|c|c|c|c|c|}
\hline Sediment parameters & $\mathrm{P} 1$ & $\mathrm{P} 2$ & $\mathrm{R} 1$ & $\mathrm{R} 2$ \\
\hline \multirow[t]{2}{*}{ Salinity } & $3.0-33.0$ & $6.0-24.0$ & $16.0-37.0$ & $16.0-37.0$ \\
\hline & 14.9 & 14.3 & 25.9 & 25.5 \\
\hline \multirow[t]{2}{*}{ Surface porosity } & $0.7-0.9$ & 0.7 & $0.4-0.9$ & $0.3-0.5$ \\
\hline & 0.9 & 0.7 & 0.7 & 0.4 \\
\hline \multirow[t]{2}{*}{ Granulometry ( $\%$ of fraction $<63 \mathrm{~mm}$ ) } & $92.1-99.7$ & $84.1-99.8$ & $35.4-80.2$ & $6.6-28.0$ \\
\hline & 97.5 & 94.6 & 59.9 & 15.2 \\
\hline \multirow[t]{2}{*}{ Water content $(\%)$} & $54.1-73.6$ & $57.6-64.1$ & $35.5-61.5$ & $16.4-33.9$ \\
\hline & 63.6 & 61.0 & 52.9 & 24.1 \\
\hline \multirow[t]{2}{*}{$\mathrm{O}_{2}$ penetration $(\mathrm{mm})$} & $0.4-1.7$ & - & $0.5-1.8$ & - \\
\hline & 1.0 & - & 0.9 & - \\
\hline \multirow[t]{2}{*}{ Organic matter (\%) } & $6.4-14.1$ & $4.2-9.2$ & $2.1-12.5$ & $1.5-8.1$ \\
\hline & 9.0 & 6.8 & 6.0 & 3.2 \\
\hline \multirow[t]{2}{*}{$\mathrm{C}: \mathrm{N}$ ratio } & $12.7-14.8$ & 14.8 & $11.9-15.0$ & 11.1 \\
\hline & 13.5 & 14.8 & 13.1 & 11.1 \\
\hline \multirow[t]{2}{*}{$\mathrm{NO}_{3}^{-}(\mu \mathrm{M})$} & $0.2-70.6$ & $0.4-1.8$ & $0.4-228.6$ & $3.0-160.3$ \\
\hline & 10.0 & 1.0 & 54.2 & 67.9 \\
\hline \multirow{2}{*}{$\mathrm{NO}_{2}^{-}(\mu \mathrm{M})$} & $0.1-2.4$ & $0.6-0.8$ & $0.0-19.1$ & $0.4-3.5$ \\
\hline & 0.8 & 0.7 & 4.9 & 2.0 \\
\hline \multirow[t]{2}{*}{$\mathrm{NH}_{4}{ }^{+}(\mu \mathrm{M})$} & $0.5-17.8$ & $2.0-3.5$ & $0.5-35.5$ & $1.0-40.1$ \\
\hline & 4.4 & 2.7 & 8.3 & 20.7 \\
\hline \multirow[t]{2}{*}{$\mathrm{PO}_{4}{ }^{3-}(\mu \mathrm{M})$} & $8.3-13.1$ & $8.5-9.8$ & $9.2-17.1$ & $8.3-17.9$ \\
\hline & 11.0 & 9.3 & 13.6 & 14.9 \\
\hline
\end{tabular}


Great differences were found in the fauna biomass of the inner and outer intertidal areas of the estuary. At P1 and P2, fauna biomass was non-existent or very scarce, with low biomass values averaging 0.15 and $0.60 \mathrm{~g}$ wet wt $\mathrm{m}^{-2}$, respectively. At R1 and R2, biomass values were comparatively higher, and monthly averages were 2338 and $1330 \mathrm{~g}$ wet wt $\mathrm{m}^{-2}$, respectively. Insects were the dominating group ( $80 \%$ of total) at P1 whereas Bivalves were the most representative benthic fauna type (52\% of total) at R1.

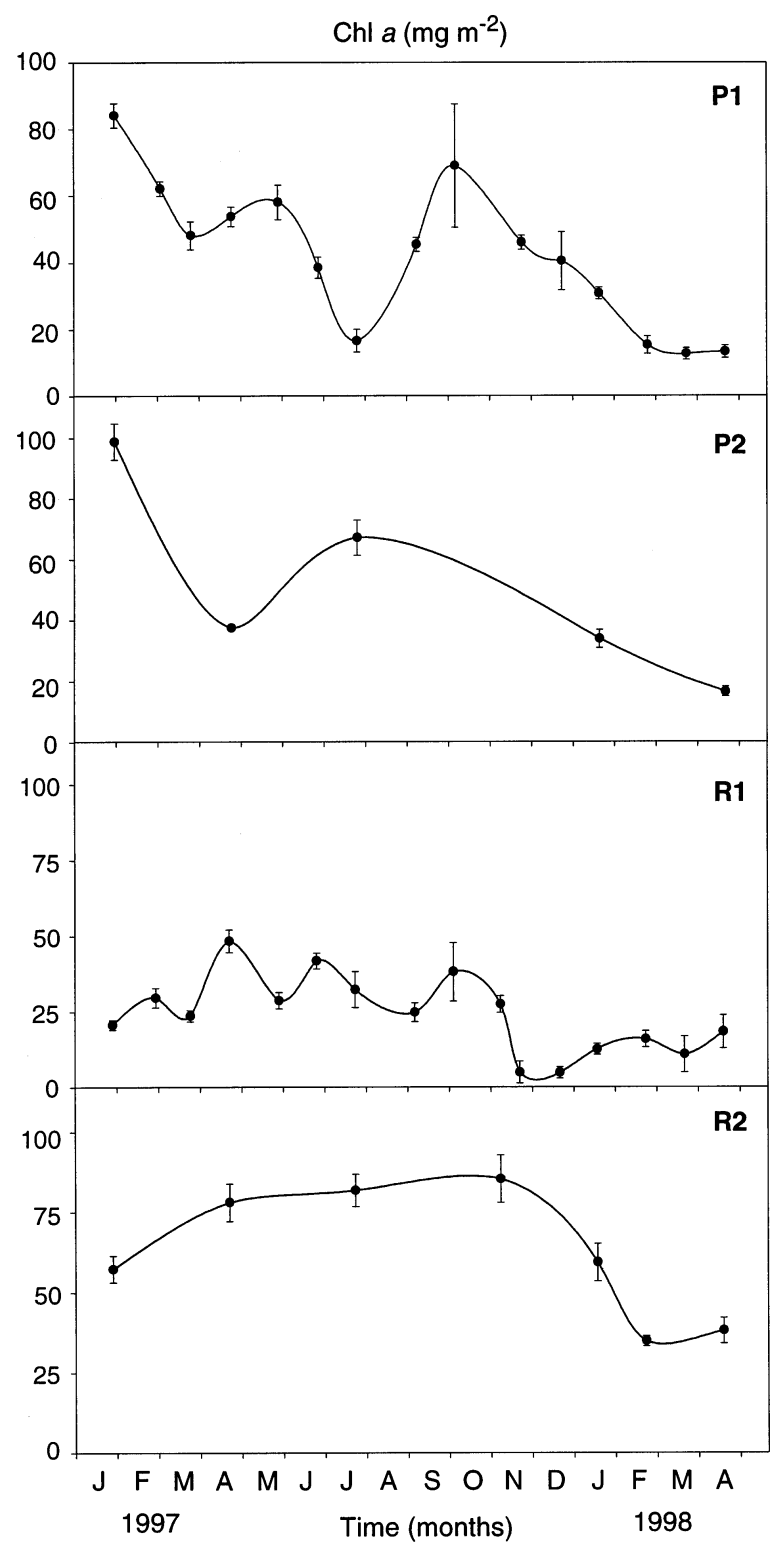

Fig. 2. Seasonal variation of microphytobenthos biomass, as $\mathrm{chl}$ a concentration $\left(\mathrm{mg} \mathrm{m}^{-2}\right)$, at the 4 intertidal sampling sites $(\mathrm{P} 1, \mathrm{P} 2, \mathrm{R} 1$ and R2), in the Tagus estuary. Bars = standard errors of the mean ( $n=5$ to 7 )

\section{$\mathrm{O}_{2}$ and DIN fluxes}

Initial incubation conditions of temperature, irradiance and $\mathrm{NO}_{3}{ }^{-}$concentration in the water column are presented in Fig. 3. Temperature and irradiance followed the corresponding annual-variation cycle. The water-column $\mathrm{NO}_{3}{ }^{-}$concentration was closely related to freshwater input into the estuary, with the highest concentrations observed in winter. Exceptionally high values $(730 \mu \mathrm{M})$ were recorded during winter at the inner station $(\mathrm{P})$.

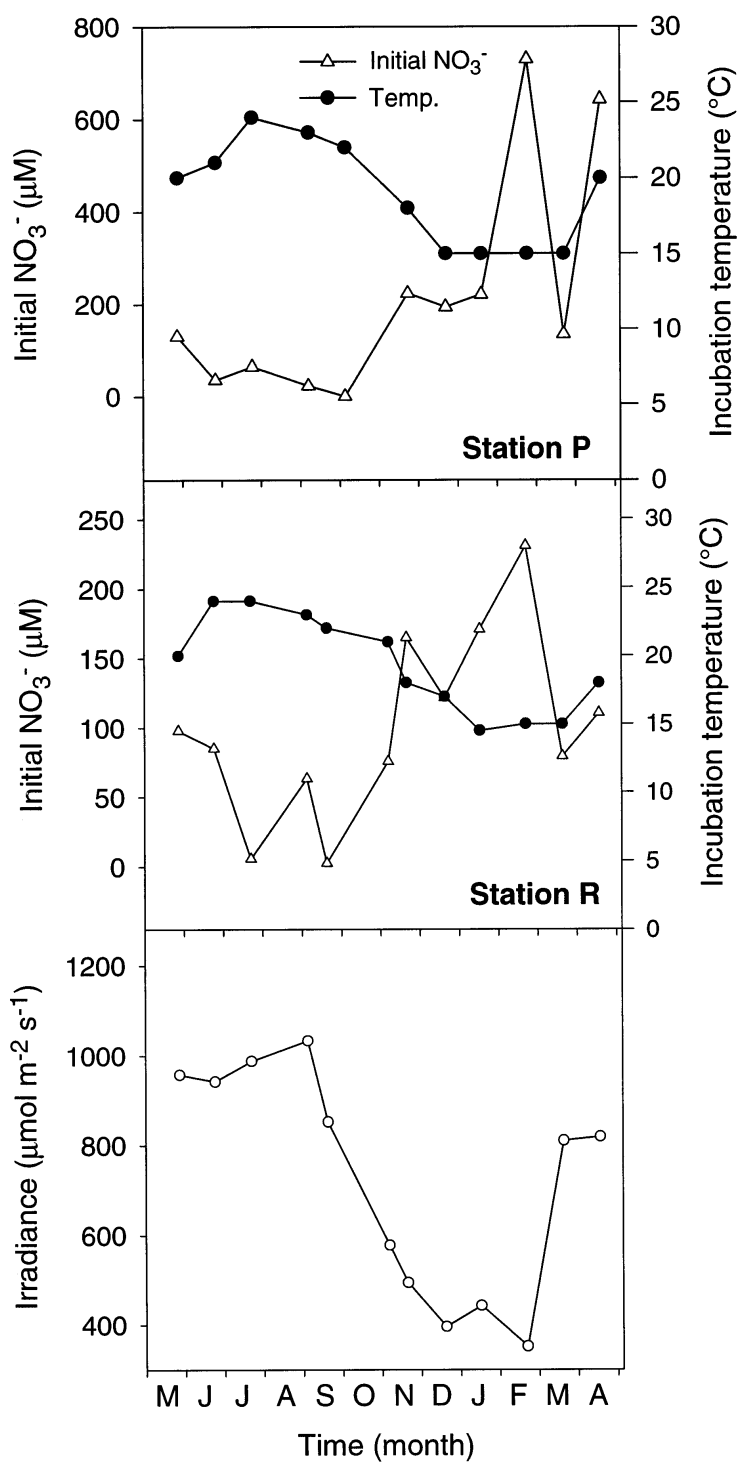

Fig. 3. Seasonal variation in temperature, irradiance and $\mathrm{NO}_{3}{ }^{-}$ concentration of the water column at the beginning of flux incubations in the upper $(\mathrm{P})$ and lower $(\mathrm{R})$ stations, during the sampling period (note the different ordinate scales) 
Fig. 4 shows $\mathrm{O}_{2}$ flux in the dark, gross primary production (GP), and $\mathrm{NO}_{3}{ }^{-}$and $\mathrm{NH}_{4}{ }^{+}$fluxes in both light and dark conditions at Sites P1 and R1. In general, oxygen uptake by the sediment was higher in summer than in the winter. Accordingly, high values of GP were also observed during the summer period, related to the high biomass in the outer part of estuary (Fig. 2). At both sites, $\mathrm{O}_{2}$ flux in the dark was significantly correlated with temperature (P1: $\mathrm{r}=-0.77, \mathrm{n}=$ $11, \mathrm{p}<0.05$; R1: $\mathrm{r}=-0.77, \mathrm{n}=12, \mathrm{p}<0.05)$.

A seasonal pattern was observed for $\mathrm{NO}_{3}{ }^{-}$fluxes, at P1 and R1 (Fig. 4). During summer, $\mathrm{NO}_{3}{ }^{-}$was generally released from the sediments. In contrast, the $\mathrm{NO}_{3}^{-}$flux was generally directed towards the sediment from October until February, covering the autumn and winter period. However, the pattern differed between the 2 sites. In winter, $\mathrm{NO}_{3}^{-}$uptake rates averaged $-120 \mu \mathrm{mol} \mathrm{m}^{-2} \mathrm{~h}^{-1}$ at $\mathrm{R} 1$, whereas at P1 influx was much higher $\left(-3500 \mu \mathrm{mol} \mathrm{m} \mathrm{m}^{-2} \mathrm{~h}^{-1}\right)$, with exceptional $\mathrm{NO}_{3}^{-}$uptake rates recorded in both light $\left(-14900 \mu \mathrm{mol} \mathrm{m} \mathrm{m}^{-2} \mathrm{~h}^{-1}\right)$ and dark $\left(-9450 \mu \mathrm{mol} \mathrm{m} \mathrm{m}^{-2} \mathrm{~h}^{-1}\right)$ conditions, during February. In summer, although $\mathrm{NO}_{3}{ }^{-}$was exported at both sites, R1 exported at a higher average rate than P1 (950 vs $360 \mu \mathrm{mol} \mathrm{m}^{-2} \mathrm{~h}^{-1}$ ).
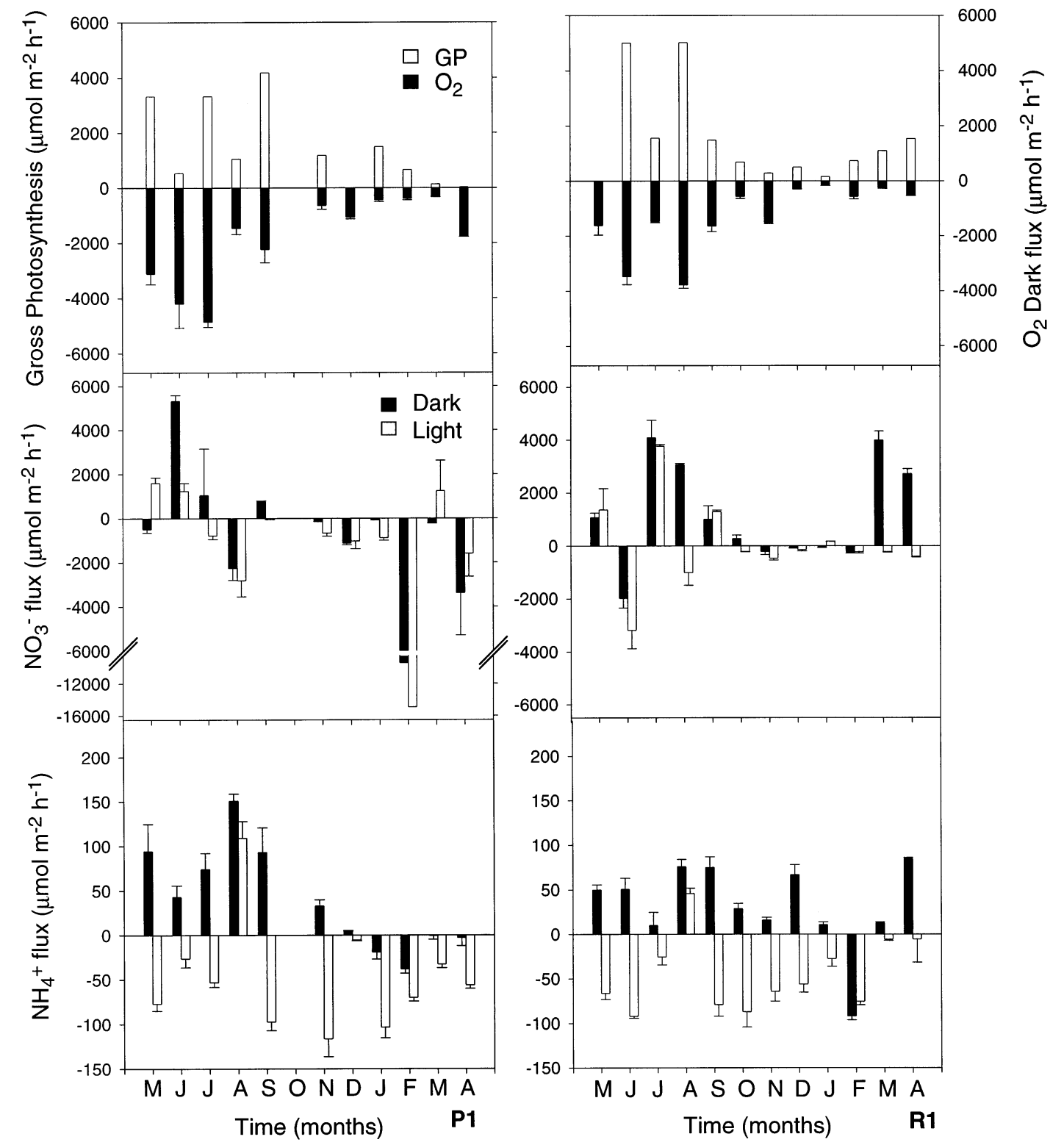

Fig. 4. Seasonal variation of $\mathrm{O}_{2}$ flux in the dark, gross primary production $(\mathrm{GP}), \mathrm{NO}_{3}{ }^{-}$and $\mathrm{NH}_{4}{ }^{+}$fluxes in both light and dark conditions, at Sites P1 and R1 in the intertidal area of the Tagus estuary (note the different ordinate scales). Bars $=$ means + $\mathrm{SE}(\mathrm{n}=3)$ 
This seasonal fluctuation is related to ambient $\mathrm{NO}_{3}{ }^{-}$ concentration fluctuations in the water column. In fact, the $\mathrm{NO}_{3}{ }^{-}$concentration in the water column was higher during autumn and winter than during spring and summer (see Fig. 3). Less $\mathrm{NO}_{3}{ }^{-}$in the water column seemed to induce the release of this nutrient from the sediment to the overlying water $(\mathrm{P} 1: \mathrm{r}=-0.75, \mathrm{n}=22$, $\mathrm{p}<0.05 ; \mathrm{R} 1: \mathrm{r}=-0.42, \mathrm{n}=24, \mathrm{p}<0.05)$.

$\mathrm{NO}_{2}^{-}$fluxes were also measured in both light and dark conditions. Generally, values were negligible in comparison with $\mathrm{NO}_{3}{ }^{-}$flux rates, at both sites: $\mathrm{NO}_{2}{ }^{-}$ flux averaged $4 \%$ of $\mathrm{NO}_{3}{ }^{-}$flux. In the outer site, $\mathrm{NO}_{2}{ }^{-}$ was released by the sediments during summer and taken up during winter, as observed for $\mathrm{NO}_{3}{ }^{-}$. At the inner site, $\mathrm{NO}_{2}^{-}$was always consumed by the sediments.

$\mathrm{NH}_{4}{ }^{+}$fluxes were also lower than $\mathrm{NO}_{3}{ }^{-}$fluxes, corresponding to 8 and $15 \%$ of $\mathrm{NO}_{3}^{-}$flux at $\mathrm{P} 1$ and $\mathrm{R} 1$, respectively. A clear pattern was observed for the $\mathrm{NH}_{4}{ }^{+}$flux, as $\mathrm{NH}_{4}{ }^{+}$was generally consumed by the sediment in the light and released from the sediment in the dark. It should be noted that the release of $\mathrm{NH}_{4}{ }^{+}$in dark conditions may also be enhanced due to hypoxia during incubation; however, this artefact effect does not influence the overall interpretation of the results.

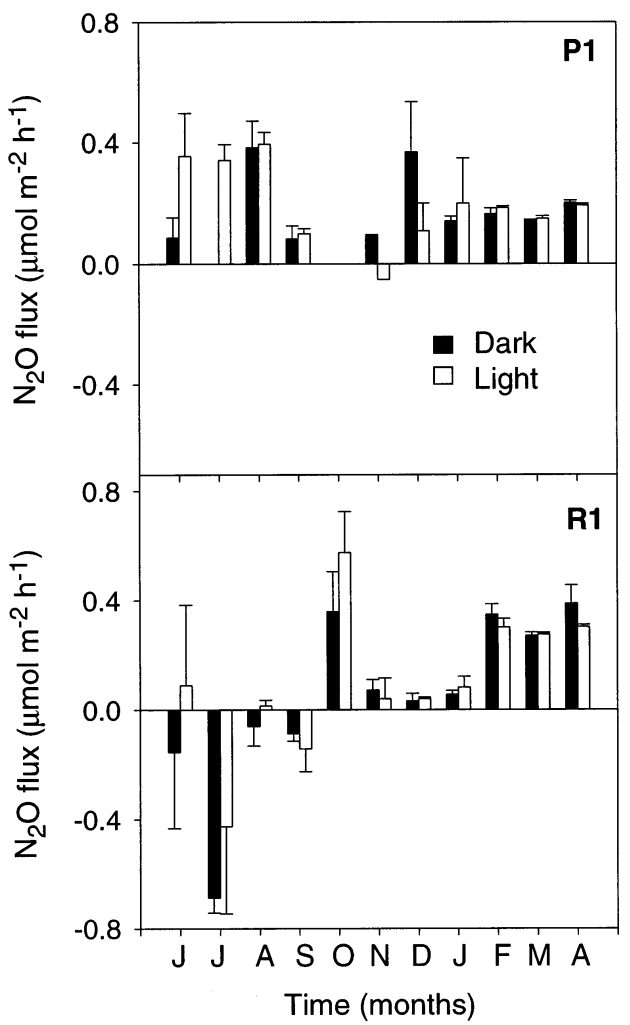

Fig. 5. Seasonal variation in $\mathrm{N}_{2} \mathrm{O}$ fluxes in light and dark conditions at Sites P1 and R1 in the intertidal area of the Tagus estuary (note the different ordinate scales). Bars $=$ means $+\mathrm{SE}$ $(\mathrm{n}=3)$
A seasonal pattern for $\mathrm{NH}_{4}{ }^{+}$flux was apparent at $\mathrm{P} 1$, but not at R1. At P1, under dark conditions, the highest rates of $\mathrm{NH}_{4}{ }^{+}$release from the sediment were detected during summer months, whereas lower efflux or even negative flux was noticed during the rest of the sampling period. In fact, a positive relationship between $\mathrm{NH}_{4}{ }^{+}$flux in the dark and temperature (P1: $\mathrm{r}=0.82, \mathrm{n}=$ $11, \mathrm{p}<0.05$ ) was observed. In addition, higher microphytobenthic biomass was also found to be associated with higher $\mathrm{NH}_{4}{ }^{+}$efflux (P1: $\mathrm{r}=0.62, \mathrm{n}=11, \mathrm{p}<$ 0.0005). In the light, the highest rates of $\mathrm{NH}_{4}^{+}$consumption by the sediment were observed during autumn and winter, decreasing in spring and summer.

\section{$\mathrm{N}_{2} \mathrm{O}$ fluxes}

$\mathrm{N}_{2} \mathrm{O}$ fluxes varied from -0.1 to $0.4 \mu \mathrm{mol} \mathrm{m} \mathrm{m}^{-2} \mathrm{~h}^{-1}$ in the inner part (P1) and from -0.7 to $0.8 \mu \mathrm{mol} \mathrm{m}{ }^{-2} \mathrm{~h}^{-1}$ in the outer part (R1) of the Tagus estuary intertidal area (Fig. 5). Differences between light and dark conditions were hardly observed, as $\mathrm{N}_{2} \mathrm{O}$ rates were comparable in both conditions. $\mathrm{N}_{2} \mathrm{O}$ release from the sediment was always observed at P1, whereas at R1, $\mathrm{N}_{2} \mathrm{O}$ uptake from the sediments occurred during summer and efflux was observed during the rest of the sampling period.

\section{Denitrification}

Seasonal variation in denitrification, namely total denitrification $\left(D_{14}\right)$, denitrification based on $\mathrm{NO}_{3}{ }^{-}$produced from nitrification $\left(D_{\mathrm{n}}\right)$, on the anoxic sediment layer and denitrification based on $\mathrm{NO}_{3}{ }^{-}$from the water column $\left(D_{\mathrm{w}}\right)$, in the inner (P1) and outer (R1) intertidal sites are shown in Fig. 6.

Denitrification rates were generally similar in both light- and dark-incubated sediments. A net pattern was observed at both sites, indicating that $D_{14}$ was highest in winter. The lowest rates were recorded in summer, reaching values below the detection limit during $\mathrm{Au}-$ gust and September. The contribution of $D_{\mathrm{n}}$ to $D_{14}$ was generally greater than that of $D_{\mathrm{w}}$, accounting for 57 to 90 and 55 to $90 \%$ of total denitrification, at P1 and R1, respectively. However, at $\mathrm{P} 1, D_{\mathrm{w}}$ accounted for $60 \%$ of total denitrification during the winter, reaching a maximum of $83 \%$ in November, in agreement with the very high $\mathrm{NO}_{3}{ }^{-}$concentrations in the water column at this time. $D_{\mathrm{n}}$ was inversely correlated with microphytobenthos biomass at R1 ( $\mathrm{r}=-0.47, \mathrm{n}=20, \mathrm{p}<0.0001)$ but not at P1. $D_{\mathrm{w}}$ was related to water column parameters, namely, $\mathrm{NO}_{3}{ }^{-}$concentration (P1: $\mathrm{r}=0.88, \mathrm{n}=10, \mathrm{p}<$ 0.0001; R1: $\mathrm{r}=0.47, \mathrm{n}=20, \mathrm{p}<0.0001$ ). 


\section{Local spatial variation}

Average values of DIN $\left(\mathrm{NO}_{3}^{-}, \mathrm{NO}_{2}^{-}\right.$and $\left.\mathrm{NH}_{4}{ }^{+}\right)$and denitrification $\left(\mathrm{N}_{2} \mathrm{O}\right.$ and $\left.\mathrm{N}_{2}\right)$ fluxes in the dark obtained on 4 occasions during summer, autumn, winter and spring, at the inner (P1, P2) and outer (R1, R2) intertidal areas, are presented in Table 2.

No spatial trend was highlighted by differences between sampling sites at the Pancas station for any of the fluxes. However, at the Rosário station, spatial differences in $\mathrm{NO}_{3}{ }^{-}$and $\mathrm{NH}_{4}{ }^{+}$fluxes were detected. $\mathrm{NO}_{3}{ }^{-}$ efflux was much higher at R1 (muddy site) than at R2

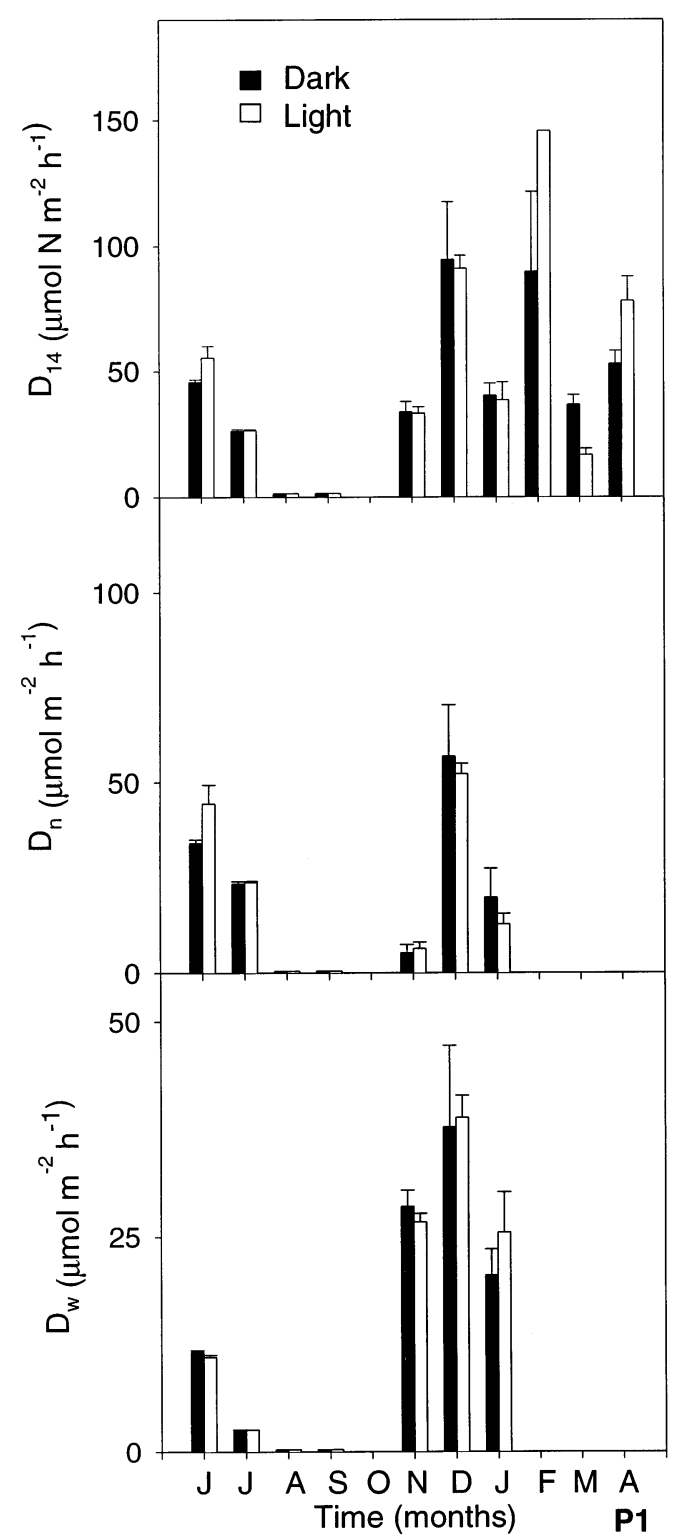

(sandy site). $\mathrm{NH}_{4}{ }^{+}$release by the sediment was 5 times higher on average at R2 than at R1.

\section{DISCUSSION}

The fluxes measured in this study reproduced 2 extreme situations occurring at the sediment-water interface. Incubations in the light simulated a state where virtually no particulate matter was suspended in the water column and therefore most light reached the sediments. The opposite state was achieved in the

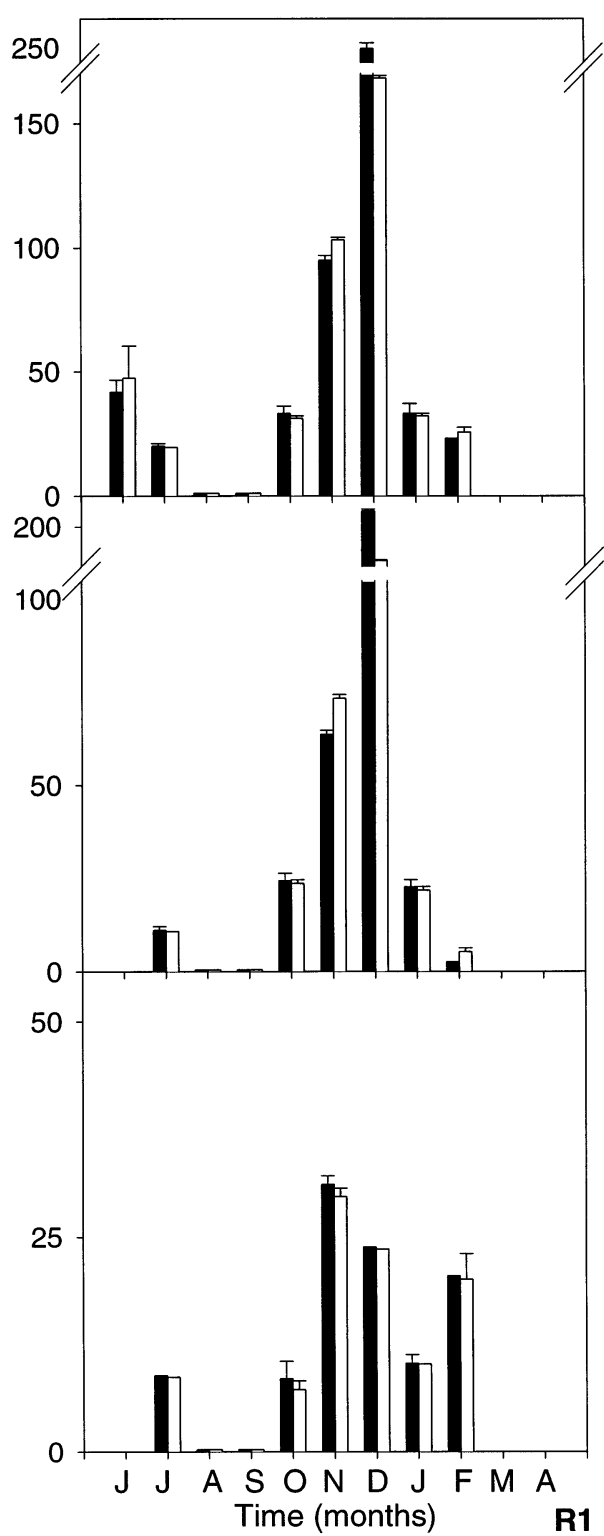

Fig. 6. Seasonal variation in total denitrification $\left(D_{14}\right)$, denitrification based on $\mathrm{NO}_{3}{ }^{-}$produced from nitrification $\left(D_{\mathrm{n}}\right)$ and denitrification based on $\mathrm{NO}_{3}{ }^{-}$from the water column $\left(D_{\mathrm{w}}\right)$, at P1 and R1 in the intertidal area of the Tagus estuary. Bars $=$ means $+\mathrm{SE}$ $(\mathrm{n}=3)$ 
Table 2. Averages of $\mathrm{O}_{2}, \mathrm{NO}_{3}{ }^{-}, \mathrm{NO}_{2}{ }^{-}, \mathrm{NH}_{4}{ }^{+}, \mathrm{N}_{2} \mathrm{O}, D_{\mathrm{n}}$ and $D_{\mathrm{w}}$ flux rates $\left(\mu \mathrm{mol} \mathrm{m} \mathrm{m}^{-2} \mathrm{~h}^{-1}\right)$ obtained in dark conditions, on 4 occasions during summer, autumn, winter and spring, at the upper $(\mathrm{P} 1, \mathrm{P} 2)$ and lower $(\mathrm{R} 1, \mathrm{R} 2)$ intertidal areas of the Tagus estuary. $D_{\mathrm{w}}=$ denitrification based on $\mathrm{NO}_{3}{ }^{-}$from water column; $D_{\mathrm{n}}=$ coupled nitrification-denitrification

\begin{tabular}{|lrrrrrrr|}
\hline Site & \multicolumn{1}{c}{$\mathrm{O}_{2}$} & $\mathrm{NO}_{3}{ }^{-}$ & $\mathrm{NO}_{2}{ }^{-}$ & $\mathrm{NH}_{4}{ }^{+}$ & $\mathrm{N}_{2} \mathrm{O}$ & $D_{\mathrm{w}}$ & $D_{\mathrm{n}}$ \\
\hline $\mathrm{P} 1$ & -2357 & -806 & -2 & 18 & 0.17 & 12 & 22 \\
$\mathrm{P} 2$ & -1853 & -435 & 8 & 26 & 0.52 & 10 & 14 \\
$\mathrm{R} 1$ & -674 & 1761 & 2 & 34 & 0.03 & 9 & 19 \\
$\mathrm{R} 2$ & -1369 & 72 & -2 & 94 & 0.06 & 7 & 17 \\
\hline
\end{tabular}

dark incubations that simulated the presence of particulate matter suspended in the water column that prevented light from reaching the sediment surface, and also simulated the night period. In the Tagus estuary, the semi-diurnal tides produce periodic cycles of emersion-immersion, generating constant variations in conditions at the surface of intertidal sediments, mainly through inundation, light exposure, and temperature fluctuation. During emersion periods, sediments remain exposed to the air and therefore fully exposed to light. During immersion periods, when sediments are covered by water, Serôdio \& Catarino (1999) have found that the maximum percentage of light reaching surface sediment was $4 \%$ during a fortnightly summer tidal cycle. Therefore, only fluxes measured in the dark did actually simulate natural conditions when sediments were inundated. Fluxes measured in the light were used here as a tool to better understand the role of microphytobenthos in nitrogen cycling across the sediment-water interface.

\section{Microphytobenthos}

The microphytobenthos was mainly composed of diatoms, as previously reported by Brotas \& PlanteCuny (1998) for the same sampling sites. Microphytobenthos biomass variation did not show a regular pattern (Fig. 2); furthermore, the results of this study, covering a 16 mo period, point to a large interannual variability. Nevertheless, microphytobenthos showed a more perceptible seasonal trend at Rosário than at Pancas sediments. Both the presence and lack of seasonality have been reported for microphytobenthos in estuarine intertidal sediments. The lack of a seasonal trend was reported by Brotas et al. (1995) for these, and other, intertidal sites of the Tagus estuary, suggesting that the mildness of the climate would prevent marked temporal changes in biomass. Authors such as Varela \& Penas (1985) and Pinckney et al. (1995), among others, have also failed to observe clear seasonal variation. Underwood \& Pater- son (1993), although reporting seasonal variation with higher biomasses during summer, point out the extreme variability of the seasonal pattern. Sediment resuspension, which is caused mainly by tidal and wind currents, affects dramatically microphytobenthic biomass (De Jonge \& Beusekom 1995); this influence is bound to produce unpredictable patterns, which may superimpose the seasonal ones.

\section{Oxygen fluxes}

Oxygen uptake by the sediment showed a distinct seasonal pattern, clearly induced by temperature, as found for other systems (Nedwell et al. 1983, Nedwell \& Trimmer 1996). $\mathrm{O}_{2}$ uptake rates, ranging from 140 to $4800 \mu \mathrm{mol} \mathrm{O} \mathrm{O}^{-2} \mathrm{~h}^{-1}$ in the intertidal sediments of the Tagus estuary, were comparable to rates observed in other ecosystems (Nedwell et al. 1983, Koop et al. 1990, Sundbäck et al. 1991, Nedwell \& Trimmer 1996). High $\mathrm{O}_{2}$-uptake values suggested a more intense benthic activity within the sediments during the summer period. Mean gross production ranged from $\sim 700 \mu \mathrm{mol}$ $\mathrm{O}_{2} \mathrm{~m}^{-2} \mathrm{~h}^{-1}$ in winter to $3000 \mu \mathrm{mol} \mathrm{O} \mathrm{O}^{-2} \mathrm{~h}^{-1}$ in summer at light levels from 100 to $1100 \mu \mathrm{mol} \mathrm{m}^{-2} \mathrm{~s}^{-1}$. Comparable values $\left(420 \mu \mathrm{mol} \mathrm{m} \mathrm{m}^{-2} \mathrm{~h}^{-1}\right)$ were found for bottom sediments in Laholm Bay, Sweden, at lower light levels $\left(20 \mu \mathrm{mol} \mathrm{m} \mathrm{m}^{-2} \mathrm{~s}^{-1}\right)$ (Sundbäck et al. 1991). Net production was frequently negative, indicating a high oxygen demand by these intertidal sediments. The effect of microphytobenthos on the oxygen conditions of emersed sediments is expected to be more powerful than during immersion periods, when no light is available for photosynthesis.

$\mathrm{O}_{2}$ uptake was slightly lower at Rosário than at Pancas. This could be related to the presence of benthic fauna in Rosário, which would increase the sedimentexchange area through burrowing activity (Pelegrí et al. 1994). As a consequence, oxygen concentration would be higher, thus reducing the oxygen demand of these sediments.

\section{DIN fluxes}

Seasonal variation of $\mathrm{NO}_{3}{ }^{-}$fluxes reflected the seasonal cycle of freshwater input in the estuary, with $\mathrm{NO}_{3}{ }^{-}$release during spring and summer and uptake in winter. Ogilvie et al. (1997) also found a strong correlation between $\mathrm{NO}_{3}{ }^{-}$uptake by sediments and water-column $\mathrm{NO}_{3}{ }^{-}$concentration in the Colne estuary (UK). In the Tagus estuary, the $\mathrm{NO}_{3}{ }^{-}$concentra- 
tion gradient across the sediment-water interface explained the seasonal variation in the $\mathrm{NO}_{3}{ }^{-}$fluxes, and also distinguished the inner from the outer sites (see Table 1 \& Fig. 3). A stronger $\mathrm{NO}_{3}{ }^{-}$concentration gradient induced higher $\mathrm{NO}_{3}^{-}$uptake by sediments in the inner area. As a whole, P1 was a sink for $\mathrm{NO}_{3}{ }^{-}$, whereas sediments at R1 were a source of this nutrient.

$\mathrm{NO}_{2}{ }^{-}$fluxes were generally very small compared to $\mathrm{NO}_{3}^{-}$fluxes but more or less followed the same trend as $\mathrm{NO}_{3}{ }^{-}$, particularly at $\mathrm{R} 1$. The proportion between $\mathrm{NO}_{2}{ }^{-}$and $\mathrm{NO}_{3}{ }^{-}$fluxes has been observed by several authors (Koop et al. 1990, Prego 1994).

$\mathrm{NH}_{4}{ }^{+}$fluxes presented a very clear pattern in regard to both seasonal variations as well as differences between light and dark fluxes. $\mathrm{NH}_{4}{ }^{+}$was consumed at light, indicating that benthic microalgae were assimilating $\mathrm{NH}_{4}{ }^{+}$, and thus reducing the amount of available $\mathrm{NH}_{4}{ }^{+}$for exchange processes between sediment and overlying water. Evidence for a reduction in $\mathrm{NH}_{4}{ }^{+}$flux to the water column by microphytobenthos, as a result of nitrogen assimilation, has been reported for other systems (Rizzo 1990, Sundbäck et al. 1991, Rysgaard et al. 1993, 1995, Thornton et al. 2000).

In short, while $\mathrm{NO}_{3}{ }^{-}$flux seemed to be controlled by $\mathrm{NO}_{3}{ }^{-}$concentration in the water column, $\mathrm{NH}_{4}{ }^{+}$flux was dependent on microalgae biomass and possibly detritical biomass (in fact, pheopigments in summer have higher values than during the rest of the year (126 vs $84 \mathrm{mg} \mathrm{m}^{-2}$ for P1 and $112 \mathrm{vs} 87 \mathrm{mg} \mathrm{m}^{-2}$ for R1).

\section{Denitrification}

Both $\mathrm{N}_{2} \mathrm{O}$ and $\mathrm{N}_{2}$ production were measured in order to evaluate denitrification in the Tagus estuary. Nitrogen loss in the form of $\mathrm{N}_{2} \mathrm{O}$ ranged from 0.01 to $0.8 \mu \mathrm{mol} \mathrm{m} \mathrm{m}^{-2} \mathrm{~h}^{-1}$. Although a limited number of $\mathrm{N}_{2} \mathrm{O}$ flux measurements have been made so far in coastal sediments, the results generally indicate an $\mathrm{N}_{2} \mathrm{O}$ release to the atmosphere varying from $<0.1$ to $9 \mu \mathrm{mol}$ $\mathrm{m}^{-2} \mathrm{~h}^{-1}$ (Seitzinger et al. 1983, 1984, Seitzinger 1990, Robinson et al. 1998); this places the Tagus estuary among those systems with lower production rates. Apparently, the $\mathrm{N}_{2} \mathrm{O}$ release found in the present study was not comparable with known industrial $\mathrm{N}_{2} \mathrm{O}$ emissions (Robinson et al. 1998).

In contrast to $\mathrm{N}_{2} \mathrm{O}, \mathrm{N}_{2}$ was produced at higher rates in the Tagus estuary, $D_{\mathrm{n}}+D_{\mathrm{w}}$ ranged from 20 to $250 \mu \mathrm{mol} \mathrm{m} \mathrm{m}^{-2} \mathrm{~h}^{-1}$. These values are within the range (5 to $250 \mu \mathrm{mol} \mathrm{m} \mathrm{m}^{-2} \mathrm{~h}^{-1}$ ) reported for other estuarine systems (Andersen et al. 1984, Seitzinger et al. 1984, Rysgaard et al. 1993, 1995, Nowicki et al. 1997, Sundbäck et al. 2000) although high denitrification rates (500 to $1300 \mu \mathrm{mol} \mathrm{m} \mathrm{m}^{-2} \mathrm{~h}^{-1}$ ) have also been found in some estuarine sediments (Seitzinger 1988, 1990, Ogilvie et al. 1997, Dong et al. 2000).

Coupled nitrification-denitrification $\left(D_{\mathrm{n}}\right)$ and denitrification based on $\mathrm{NO}_{3}{ }^{-}$from the water column $\left(D_{\mathrm{w}}\right)$ both displayed the same seasonal trend, with highest values in the winter and lowest during the summer. The reduced $D_{\mathrm{n}}$ activity in summer appeared to be a consequence of the low $\mathrm{NO}_{3}{ }^{-}$and $\mathrm{NH}_{4}{ }^{+}$concentrations in the water column, concomitant with a higher microphytobenthos biomass. Release of $\mathrm{NO}_{3}{ }^{-}$from the sediment, as well as competition for $\mathrm{NH}_{4}{ }^{+}$between benthic microalgae and nitrifiers, both enhanced during summer, reduced the amount of nitrogen available in the sediment and explained the lower denitrification rates. This was also observed in estuarine sediments by Rysgaard et al. (1995). Evidence that benthic microalgae are efficient competitors of nitrifying bacteria at low nitrogen concentrations was shown by Rysgaard et al. (1993, 1995) and Risgaard-Petersen et al. (1994). In winter, the higher inorganic nitrogen concentrations in the water column would reduce competition for nitrogen within the sediment. A higher $\mathrm{NH}_{4}{ }^{+}$concentration in the sediments would thus stimulate nitrification and, consequently, $D_{\mathrm{n}}$.

No differences between light and dark fluxes were detected (Fig. 5). A different situation was observed by Rysgaard et al. (1995) during the cold season in sediments from a shallow estuary, showing that benthic microalgae stimulated coupled nitrificationdenitrification as a result of $\mathrm{O}_{2}$ production when nitrogen availability was high. The effect of microphytobenthos seasonal variation on coupled nitrificationdenitrification in the Tagus estuary sediments was more likely related to changes in biomass, causing competition, than to $\mathrm{O}_{2}$ production by photosynthesis.

From the denitrification field studies carried out todate, it is difficult to isolate the effect of temperature, DIN concentration, photosynthesis of microalgae and activity of infauna which, in turn, are partially interdependent. It is quite clear from most studies that an addition in $\mathrm{NO}_{3}{ }^{-}$from freshwater input (in late winter and early spring in northern hemisphere) causes a severe increase in total denitrification, mainly through a rise in $D_{\mathrm{w}}$ (Rysgaard et al. 1995, Ogilvie et al. 1997). This was also found in the present study, more evidently at the inner site (P1).

Differences in $D_{\mathrm{w}}$ between light and dark conditions were not found, in contrast with results obtained by other authors (Christensen et al. 1990, RisgaardPetersen et al. 1993, Rysgaard et al. 1995), who found a slight decrease in $D_{\mathrm{w}}$ under light conditions due to the effect of photosynthesis and increasing $\mathrm{O}_{2}$ penetration depth, which was reflected on the time lag that $\mathrm{NO}_{3}{ }^{-}$took to reach the anaerobic layer by diffusion. In the Tagus system, the small thickness of oxic layer (Table 1) might not permit these differences to occur. 
During emmersion periods, different diffusion rates are likely to occur, therefore, to obtain a full picture of the denitrification process, a complete study should be addressed, covering all situations. Denitrification rates during emmersion periods in a Tagus estuary intertidal mudflat have been measured by Ottosen et al. (2000) in June 1998. These authors measured negligible coupled nitrification-denitrification rates during the day. On the same occasion, light and dark denitrification rates were measured in exposed and inundated sediment cores (data not published); the results obtained on both situations were quite similar.

Local spatial variability within each station (P1 vs P2 and R1 vs R2) was only evident at Rosário, where sediment characteristics were very different between sites (Table 2). R2 sediments were typically sandy, having, on average, higher microphytobenthos (R2: 62; R1: $24 \mathrm{mg} \mathrm{chl} \mathrm{a} \mathrm{m}^{-2}$ ) biomass and also higher porewater $\mathrm{NH}_{4}{ }^{+}$concentration (R2: 21; R1: $8 \mu \mathrm{M}$ ). There was a higher oxygen demand at $\mathrm{R} 2$ than at R1, indicated by the higher $\mathrm{O}_{2}$ input into the sediments and lower $\mathrm{NO}_{3}{ }^{-}$ efflux. The more dense benthic communities would be responsible for this high requirement in oxygen at R2. The higher $\mathrm{NH}_{4}{ }^{+}$efflux at $\mathrm{R} 2$ could be explained by the fact that sandy sediments have a lower adsorption capacity than muddy sediments, regarding positive ions such as $\mathrm{NH}_{4}{ }^{+}$(Simon 1988). Apparently, differences of site location in relation to tidal height within each station, did not contribute to any detectable spatial variability.

Fig. 7 shows the relative importance of DIN fluxes and denitrification on an annual basis, for P1 and R1. Most of the estuarine intertidal sediments are situated below $2.0 \mathrm{~m}$ (tidal height) corresponding to a total area of $100 \mathrm{~km}^{2}$ whereas only $14 \mathrm{~km}^{2}$ are equal or above $2.0 \mathrm{~m}$. The figure clearly shows the differences in nitrogen balance between the Pancas and Rosário sediments, which is also related to the immersion period. DIN availability was estimated to be 5500 to $6000 \mathrm{mmol} \mathrm{m}^{-2} \mathrm{yr}^{-1}$, on average, in the outer and inner site, from monthly measurements of concentration in the water column multiplied by the river flow. As a whole, Rosário (R1) acted as a more effective source of nitrogen to the estuarine water column, than Pancas (P1). Major differences were noticed in regard to DIN; while sediments were a source of all DIN forms at the $\mathrm{R} 1, \mathrm{NH}_{4}{ }^{+}$was the only nitrogen form released to the water column, at P1. Ammonium and $\mathrm{N}_{2}$ were more intensely released to the water column at R1, because sediments remained inundated for longer periods of time, since hourly rates were fairly comparable at both sites.

The DIN concentration was 224 and $107 \mu \mathrm{M}$, on average, in the water column of the inner and outer

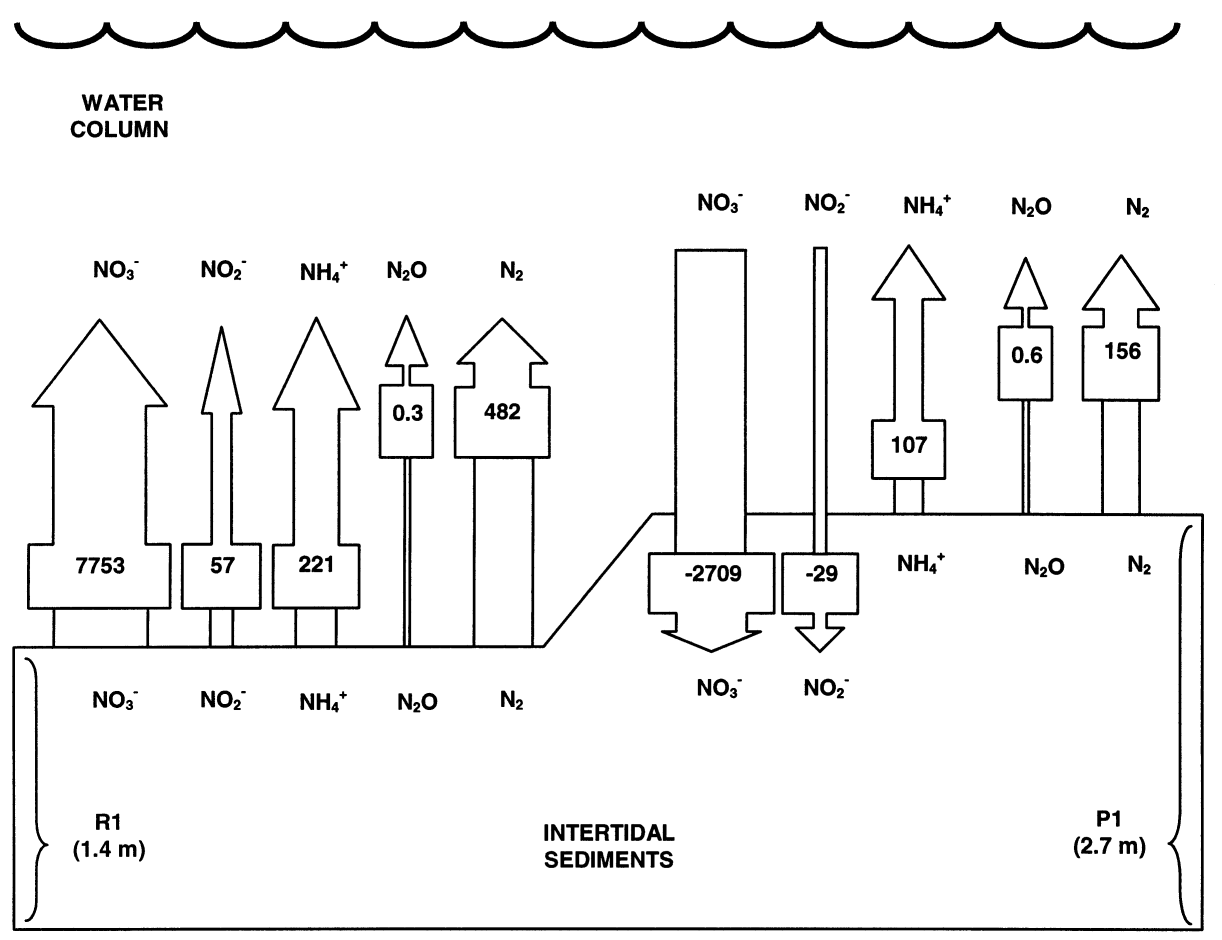

Fig. 7. Annual nitrogen fluxes at the sediment water-interface, calculated from dark fluxes and adjusted according to the daily period of immersion for Sites P1 and R1 (considered as representative sites of the upper and lower intertidal areas, respectively) All values are in $\mathrm{mmol} \mathrm{m}^{-2} \mathrm{yr}^{-1}$ 
sites. DIN concentration just outside the estuary throughout 1 yr was $8 \mu \mathrm{M}$ (Cabrita 1997), and $17 \mu \mathrm{M}$ in early spring (Cabeçadas et al. 1999). The latter authors found that the influence of the river plume outside the estuary created a gradient of ca $30 \mathrm{~km}$, until nutrient concentrations reached typical coastal values. Considerable amounts of nitrogen would, then, remain within the estuary and, hence, nitrogen-consuming processes responsible for the reduced nitrogen outflow from the estuary to the adjacent coastal waters must occur within the estuarine basin.

A typical feature of Tagus estuary is that porewater nutrient concentrations are equal to or lower than those of the water column, in particular for $\mathrm{NO}_{3}{ }^{-}$, which is present in much higher concentrations in the water column (cf. Table 1 \& Fig. 3). The N:P ratio measured in the interstitial water was 1.8 for P1 and 6.5 for R1 (annual average); these values are lower than those reported for the water column and remarkably lower than the conventional Redfield ratio of 16:1. These ratios suggest that $\mathrm{N}$ could be limiting in the sediments, mostly due to low $\mathrm{NO}_{3}{ }^{-}$concentrations. The assumption that nitrogen would be nearly completely assimilated by microalgae, contributes also to justify the low values found for denitrification rates measured in Tagus estuary, during summer.

N-removal by denitrification was estimated on the basis of monthly values of DIN available in the water column. On an annual basis, the conclusion was that denitrification accounted for $3 \%$ of the total DIN in the inner site (P1) and for $9 \%$ in the outer site (R1). This latter value can be extrapolated to the majority of Tagus intertidal mudflats, as the outer site is representative of $90 \%$ of the estuarine intertidal area. Previous studies in the Tagus estuary in November 1983 (Seitzinger 1988) recorded very high denitrification rates $\left(232 \mu \mathrm{mol} \mathrm{m} \mathrm{m}^{-2} \mathrm{~h}^{-1}\right)$ which, together with a DIN river input of $516 \mu \mathrm{mol} \mathrm{m}{ }^{-2} \mathrm{~h}^{-1}$, indicates that as much as $45 \%$ was denitrified. The maximum denitrification rate $\left(D_{\mathrm{n}}+D_{\mathrm{w}}\right)$ recorded in the present study was $250 \mu \mathrm{mol} \mathrm{m} \mathrm{m}^{-2} \mathrm{~h}^{-1}$ versus $554 \mu \mathrm{mol} \mathrm{m} \mathrm{m}^{-2} \mathrm{~h}^{-1}$ available DIN (in R1 during December), giving a N-removal of $35 \%$ when the immersion period is taken into account. For the inner site P1, the maximum value was only $4 \%$ in the same month. The range of this variation underlines the importance of seasonal evaluation for accurately quantifying any process in an ecosystem.

Therefore, it can be concluded that denitrification in the intertidal areas of the Tagus estuary was not a major process in N-removal. Nitrogen assimilation by microalgae could also be a considerable $\mathrm{N}$ sink within the estuary. Microphytobenthos assimilation rates, estimated from primary production rates (see Fig. 4), averaged $90 \mu \mathrm{mol} \mathrm{m} \mathrm{m}^{-2} \mathrm{~h}^{-1}$. Nitrogen assimilation rate was estimated as ca 2 to $4 \mu \mathrm{mol} \mathrm{N}$ mg $\mathrm{chl} \mathrm{h}^{-1}$ (mean annual values for both sites), which suggests that a large quantity of nitrogen is retained within benthic microalgae. The assimilation:denitrification ratio varied from 0.1 to 9 , with a mean of 2 , showing the relative importance of these 2 processes in intertidal mudflats. Previous studies reported that nitrogen uptake by phytoplankton removed a fraction of DIN available equivalent to $27 \%$ (Cabrita 1997).

The fate of $\mathrm{N}$ within cells depends on the fate of cells. Algal biomass may be either exported to the continental shelf, buried in sediments, or consumed (Fisher et al. 1992). Burial of active microphytobenthic cells arises mainly from sediment disturbance caused by physical processes and biota (De Jonge \& Colijn 1994); Brotas \& Serôdio (1995) estimated a burial rate for chl a of $0.27 \mathrm{~mm} \mathrm{~d}^{-1}$ at the lower site (R1), meaning that cells would suffer a positive burial in the sediment in the order of $10 \mathrm{~cm} \mathrm{yr}^{-1}$, in the absence of stormy events. Presumably, apart from burial within the sediment, an important fraction of the particulate nitrogen is also transferred to higher trophic levels of the estuarine food web, also contributing to nitrogen removal from the water column and sediments. Removal of nitrogen in the Tagus estuary was more probably the result of the joint effect of these latter processes together with denitrification, their relative importance being subject to seasonal fluctuations.

Acknowledgements. The authors are grateful to J. Serôdio, R. Godinho, L. Ribeiro, P. Marques and B. Jesus for valuable assistance in field and laboratory work. We also wish to thank the Zoology Group of the Instituto de Oceanografia for infauna counting and identification. This research was supported by the European Union ELOISE program under the framework of NICE project, Contract MAS3-CT96-0048.

\section{LITERATURE CITED}

Andersen TK, Jensen MH, Sørensen J (1984) Diurnal variation of nitrogen cycling in coastal, marine sediments. Mar Biol 83:171-176

Bendschneider K, Robison NJ (1952) A new spectrophotometric determination of nitrite in seawater. J Mar Res 11: $87-96$

Boynton WR, Kemp WM (1985) Nutrient regeneration and oxygen consumption by sediments along an estuarine salinity gradient. Mar Ecol Prog Ser 23:45-55

Brotas V, Catarino F (1995) Microphytobenthos primary production of Tagus estuary intertidal flats (Portugal). Neth J Aquat Ecol 29(4):333-339

Brotas V, Plante-Cuny MR (1998) Spatial and temporal patterns of microphytobenthic taxa of estuarine tidal flats in the Tagus estuary using pigment analysis by HPLC. Mar Ecol Prog Ser 171:43-57

Brotas V, Serôdio J (1995) A mathematical model for the vertical distribution of chlorophyll $a$ in estuarine intertidal sediments. Neth J Aquat Ecol 29(4):315-321 
Brotas V, Cabrita MT, Portugal A, Serôdio J, Catarino F (1995) Spatio-temporal distribution of microphytobenthic biomass in tidal flats of the Tagus estuary (Portugal). Hydrobiologia 300/301:93-104

Cabeçadas L, Brogueira MJ, Cabeçadas G (1999) Phytoplankton spring bloom in the Tagus adjacent coastal waters: hidrological and chemical associated conditions. Aquat Ecol 33:243-250

Cabrita MT (1997) Inorganic nitrogen dynamics in the Tagus estuary (Portugal). Spatial and temporal variation in input and uptake of nitrate and ammonium. PhD thesis, University of Lisbon (Portugal), Mediterranean University (AixMarseille II, France)

Christensen PB, Nielsen LP, Sørensen J, Revsbech NP (1990) Denitrification in nitrate-rich streams: diurnal and seasonal variation related to benthic oxygen metabolism. Limnol Oceanogr 33(3):640-651

Constanza R, D'Arge R, de Groot R, Farber S, Grasso M, Hannon B, Limburg K, Naeem S, O'Neill R, Paruelo J, Raskin RG, Sutton P, van den Belt M (1997) The value of the world's ecosystem services and natural capital. Nature 387:253-260

Dalsgaard T (ed) Nielsen LP, Brotas V, Viaroli P, Underwood G, Nedwell D, Sundbäck K, Rysgaard S, Miles A, Bartoli M, Dong L, Thornton DCO, Ottosen LDM, Castaldelli G, Risgaard-Petersen N (2000) Protocol handbook for NICE - Nitrogen cycling in estuaries: a project under the EU programme Marine Science and Technology (MAST III). National Environmental Research Institute, Silkeborg

De Jonge VN, Beusekom JEE (1995) Wind- and tide-induced resuspension of sediment and microphytobenthos from tidal flats in the Ems estuary. Limnol Oceanogr 40(4): 766-778

De Jonge VN, Colijn F (1994) Dynamics of microphytobenthos biomass in the Ems estuary. Mar Ecol Prog Ser 104: 185-196

Dong LF, Thornton DCO, Nedwell DB, Underwood GJC (2000) Denitrification in the sediments of the River Colne estuary, England. Mar Ecol Prog Ser (in press)

Eaton EJ, Moss B (1966) The estimation of numbers and pigment content in epipelic algal populations. Limnol Oceanogr 11:584-595

Fisher TR, Peele, ER, Ammerman JW, Harding Jr LW (1992) Nutrient limitation of phytoplankton in Chesapeake Bay. Mar Ecol Prog Ser 82:51-63

Grasshoff K (1976) Methods of seawater analysis. Verlag Chimie, New York

Jensen MH, Lomstein E, Sørensen J (1990) Benthic $\mathrm{NH}_{4}{ }^{+}$and $\mathrm{NO}_{3}{ }^{-}$flux following sedimentation of a spring phytoplankton bloom in Aarhus Bight, Denmark. Mar Ecol Prog Ser 61:87-96

Koop K, Boynton WR, Wulff F, Carman R (1990) Sediment-water oxygen and nutrient exchanges along a depth gradient in the Baltic Sea. Mar Ecol Prog Ser 63: 65-77

Koroleff F (1969/1970) Direct determination of ammonia in natural waters as indophenol blue. Int Counc Explor Sea (ICES) Comm Meet Pap 1969/C:9; revised 1970, $19-22$

Lorenzen CJ (1967) Determination of chlorophyll and phaeo-pigments: spectrophotometric equations. Limnol Oceanogr 12:343-346

Murphy J, Riley JP (1962) A modified single solution method for the determination of phosphate in natural waters. Anal Chim Acta 27:301-318

Nedwell DB, Trimmer M (1996) Nitrogen fluxes through the upper estuary of the Great Ouse, England: the role of the bottom sediments. Mar Ecol Prog Ser 142:273-286

Nedwell DB, Hall SE, Andersson A, Hagström AF, Lindström EB (1983) Seasonal changes in the distribution and exchange of inorganic nitrogen between sediment and water in the Northern Baltic (Gulf of Bothnia). Estuar Coast Shelf Sci 17:169-179

Nielsen LP (1992) Denitrification in sediment determined from nitrogen isotope pairing. FEMS Microbiol Ecol 86: 357-362

Nixon, SW (1981) Remineralization and nutrient cycling in coastal marine ecosystems. In: Neilson BJ, Cronin LE (eds) Estuaries and nutrients. Humana Press, Clifton, NJ, p 111-138

Nowicki BL, Kelly JR, Requintina E, Van Keuren D (1997) Nitrogen losses through sediment denitrification in Boston Harbor and Massachusetts Bay. Estuaries 20(3): 626-639

Ogilvie B, Nedwell DB, Harrison RM, Robinson A, Sage A (1997) High nitrate, muddy estuaries as nitrogen sinks: the nitrogen budget of the River Colne estuary (United Kingdom). Mar Ecol Prog Ser 150:217-228

Ottosen L, Risgaard-Petersen N, Nielsen LP, Dalsgaard T (2000) Denitrification in exposed intertidal mud flats. Mar Ecol Prog Ser (in press)

Pelegrí SP, Nielsen LP, Blackburn TH (1994) Denitrification in estuarine sediment stimulated by the irrigation activity of the amphipod Corophium volutator. Mar Ecol Prog Ser 105:285-290

Pinckney J, Pearl HW, Fitzpatrick M (1995) Impacts of seasonality and nutrients on microbial mat community structure and function. Mar Ecol Prog Ser 123:207-216

Prego R (1994) Nitrogen interchanges generated by biogeochemical processes in a Galician ria. Mar Chem 45: 167-176

Rasmussen RA, Krasnec J, Pierotti D (1976) $\mathrm{N}_{2} \mathrm{O}$ analysis in the atmosphere via electron capture gas chromatography. Geophys Res Lett 34:1004-1013

Risgaard-Petersen N, Rysgaard S, Revsbech NP (1993) A sensitive assay for determination of ${ }^{14} \mathrm{~N} /{ }^{15} \mathrm{~N}$ isotope distribution in $\mathrm{NO}_{3}^{-}$. J Microbiol Methods 17:155-164

Risgaard-Petersen N, Rysgaard S, Nielsen LP, Revsbech NP (1994) Diurnal variation of denitrification and nitrification in sediments colonized by benthic microphytes. Limnol Oceanogr 39(3):573-579

Rizzo WM (1990) Nutrient exchanges between the water column and a subtidal benthic microalgal community. Estuaries 13(3):219-226

Robinson AD, Nedwell DB, Harrison RM, Ogilvie BG (1998) Hypernutrified estuaries as sources of $\mathrm{N}_{2} \mathrm{O}$ emission to the atmosphere: the estuary of the River Colne, Essex, UK. Mar Ecol Prog Ser 164:59-71

Rysgaard S, Risgaard-Petersen N, Nielsen LP, Revsbech NP (1993) Nitrification and denitrification in lake and estuarine sediments measured by the ${ }^{15} \mathrm{~N}$ dilution technique and isotope pairing. Appl Environ Microbiol 59(7): 2093-2098

Rysgaard S, Christensen PB, Nielsen LP (1995) Seasonal variation in nitrification and denitrification in estuarine sediment colonized by benthic microalgae and bioturbating infauna. Mar Ecol Prog Ser 126:111-121

Seitzinger SP (1987) Nitrogen biochemistry in an unpolluted estuary: the importance of benthic denitrification. Mar Ecol Prog Ser 37:65-73

Seitzinger SP (1988) Denitrification in freshwater and coastal marine ecosystems: ecological and geochemical significance. Limnol Oceanol 33(4):702-724 
Seitzinger SP (1990) Denitrification in aquatic sediments. In: Revsbeck NP, Sørensen J (eds) Denitrification in soil and sediment. Plenum Press, New York, p 301-322

Seitzinger SP, Pilson MEQ, Nixon SW (1983) Nitrous oxide production in nearshore marine sediments. Science 222: $1244-1246$

Seitzinger SP, Nixon SW, Pilson MEQ (1984) Denitrification and nitrous oxyde production in a coastal marine ecosystem. Limnol Oceanol 29:73-83

Serôdio J, Catarino F (1999) Fortnightly light and temperature variability in estuarine intertidal sediments and implications for microphytobenthos primary productivity. Aquat Ecol 33:235-241

Simon NS (1988) Nitrogen cycling between sediment and the shallow-water column in the transition zone of the Potomac river and estuary. I. Nitrate and ammonium fluxes. Estuar Coast Shelf Sci 26:483-497

Strickland JDH, Parsons TR (1972) A practical handbook of seawater analysis. Bull Fish Res Board Can 167

Editorial responsibility: Otto Kinne (Editor),

Oldendorf/Luhe, Germany
Sundbäck K, Enokson V, Granéli W, Petterson K (1991) Influence of sublittoral microphytobenthos on the oxygen flux between sediment and water: a laboratory continuous-flow study. Mar Ecol Prog Ser 74:263-279

Sundbäck K, Miles A, Göransson E (2000) Nitrogen fluxes, denitrification and the role of microphytobenthos in microtidal shallow-water sediments: An annual study. Mar Ecol Prog Ser 200:59-76

Thornton DCO, Underwood GJC, Nedwell DB (2000) Effect of illumination and emersion period on the exchange of ammonium across the estuarine sediment-water interface. Mar Ecol Prog Ser 184:11-20

Underwood GJC, Paterson DM 1993. Seasonal changes in diatom biomass, sediment stability and biogenic stabilization in the Severn estuary. J Mar Biol Assoc UK 73: 871-887.

Varela M, Penas E (1985) Primary production of benthic microalgae in an intertidal sand flat of the Ria de Arosa, NW Spain. Mar Ecol Prog Ser 25:111-119

Submitted: July 7, 1999; Accepted: January 7, 2000

Proofs received from author(s): July 24, 2000 